\title{
EFEKTIVITAS IKLAN YOUTUBE TRAVELOKA TERHADAP KEPUTUSAN PEMBELIAN \\ (Studi EPIC Model pada Iklan YouTube "Saat Memesan Tiket Pesawat Tak Lagi Ribet" pada Karyawan di Jakarta)
}

\author{
Adelia Dinda ${ }^{1}$, Donatella Rara ${ }^{2}$, Irwansyah ${ }^{3}$ \\ 123 Universitas Indonesia

\begin{tabular}{|c|c|c|}
\hline Received: 21 Desember 2017 & Revised: 09 Februari 2018 & Accepted: 15 Maret 2018 \\
\hline \multicolumn{3}{|c|}{ Available online at: bit.do/demandia }
\end{tabular}

\begin{abstract}
Abstrak: Traveloka merupakan platform pemesanan tiket online terbesar di Indonesia yang memiliki lebih dari 15 juta pengunduh. Kegiatan pemasaran yang dilakukan untuk meningkatkan penggunaan aplikasi Traveloka salah satunya adalah dengan menayangkan iklan di YouTube. Iklan yang ditayangkan oleh Traveloka dapat dianalisis menggunakan model EPIC oleh AC Nielsen untuk mengetahui efektivitas iklan dalam memengaruhi keputusan pembelian. Penelitian kuantitatif ini menggunakan metode non probability sampling dengan quota sampling untuk mengumpulkan data, dengan sampel penelitian para karyawan yang bekerja dan berdomisili di DKI Jakarta. Penelitian ini melibatkan variabel dependen yaitu keputusan pembelian dan variabel independen yang berupa emphaty, persuasion, impact, dan communication. Penelitian ini melibatkan 120 responden. Hasil penelitian menyatakan bahwa setiap variabel EPIC efektif terhadap keputusan pembelian, dengan hasil EPIC rate sebesar 3,89.

Kata kunci: Efektivitas iklan, model EPIC, Traveloka, YouTube, keputusan pembelian
\end{abstract}

\begin{abstract}
Online ticket reservation platform Traveloka is the biggest online ticket reservation platform in Indonesia with approximately 15 million downloaders. One of the marketing strategy that is done to boost the usage of Traveloka application is by running a Youtube advertisement. Traveloka's YouTube advertisement can be analyzed by AC Nielsen's EPIC model to evaluate the effectiveness of those advertisements in influencing the purchasing decision. This quantitative research uses non probability sampling and quota sampling method to collect data. This studies take employees in Jakarta as a research sample. This research involves purchase decision as the dependent variable and empathy, persuasion, impact, and communication as the independent variables. This research involved 120 respondents. The result shows that each of EPIC variable is effective towards the purchase decision, with EPIC rate of 3.89.
\end{abstract}

Keywords: advertisement effectivity, EPIC model, Traveloka, YouTube, purchase decision

\footnotetext{
${ }^{1}$ Mahasiswi Program Studi IImu Komunikasi FISIP UI, email: adelia.dinda@ui.ac.id

${ }^{2}$ Mahasiswi Program Studi IImu Komunikasi FISIP UI, email: donatella.rara@ui.ac.id

3 Pengajar Program Studi IImu Komunikasi FISIP UI, email: dr.irwansyah.ma@gmail.com
} 


\section{PENDAHULUAN}

Bepergian ke luar kota atau ke luar negeri menjadi salah satu kegiatan yang banyak dilakukan, baik untuk kepentingan profesional seperti perjalanan bisnis atau sekadar liburan. Pemesanan tiket yang dahulu biasa dilakukan melalui travel agent atau loket di stasiun maupun bandara kini telah bergeser ke layanan pemesanan tiket online seperti yang dilakukan oleh Traveloka.

Didirikan pada tahun 2012, kini Traveloka merupakan platform pemesanan tiket online terbesar dengan lebih dari 15 juta pengunduh. Banyaknya pengguna Traveloka didukung dengan cukup besarnya transaksi untuk pemesanan tiket dan perjalanan di e-commerce Indonesia. Pada 2015, total transaksi dari bidang tersebut mencapai angka 35.3\% dari seluruh sektor jasa yang berjualan di sektor e-commerce. (Kementerian Komunikasi dan Informasi, 2015). Posisi Traveloka sebagai platform pemesanan tiket online terbesar semakin diperkuat dengan beragam penghargaan, seperti Google Play: The Best App in 2015 (Widiartanto, 2015) dan penghargaan 20 Rising Global Stars. (Forbes Indonesia, 2016)

Meskipun saat ini Traveloka merupakan platform pemesanan tiket online terbesar, Traveloka terus melakukan kegiatan pemasaran dengan gencar, salah satunya melalui iklan YouTube. Berdasarkan Website Analysis Overview Report traveloka.com, jumlah iklan Traveloka yang ditayangkan di platform YouTube mencapai 35.83\% dari total iklan digital Traveloka per Juli-September 2017. Lebih lanjut, YouTube menempati posisi kedua di bidang media sosial yang menyumbang traffic traveloka.com sebesar 38.80\%. (Pro Similar Web, 2017).

Sejalan dengan itu, YouTube dianggap efektif karena setidaknya $36 \%$ konsumen online menaruh kepercayaan terhadap advertisement video (Grimes, 2012). Generasi muda dengan umur berkisar dari 18 sampai 34 tahun juga lebih sering menggunakan YouTube daripada televisi kabel, serta merupakan frekuensi pengguna terbesar YouTube (Perrin, 2015). 
Salah satu iklan Traveloka yang ditayangkriman di YouTube adalah iklan "Saat Memesan Tiket Pesawat Tak Lagi Ribet" versi Nycta Gina dan Risky Kinoz, yang diiklankan di kanal YouTube Traveloka sejak 12 Juni 2017. Iklan ini memperoleh view terbanyak dibandingkan iklan Traveloka lainnya, yakni sebanyak 36 juta penonton hingga saat ini. Untuk mengukur efektivitas iklan ini, peneliti menggunakan EPIC (Empathy, Persuasion, Impact, Communication) Model yang dikembangkan oleh lembaga riset AC Nielsen, untuk kemudian meneliti pengaruhnya terhadap keputusan pembelian karyawan yang bekerja di DKI Jakarta.

Pemilihan karyawan sebagai responden penelitian didasarkan pada hasil survei pengguna Internet yang menunjukkan bahwa sejumlah 62\% dari 132,7 juta pengguna Internet merupakan pekerja atau wiraswasta. Lebih lanjut, sekitar $25,7 \%$ dari 34,1 juta total pengguna internet di Indonesia ini melakukan pembelian tiket secara online (APJII, 2016). Pemilihan responden juga didukung oleh data dari Statistik Profil Wisatawan Nusantara 2014 yang menunjukkan bahwa buruh/karyawan/pegawai adalah pekerjaan utama di DKI Jakarta yang paling sering melakukan perjalanan dengan hasil persentase sebesar 57,02\% (Kementerian Pariwisata, 2014) .

\section{KAJIAN TEORI}

Kotler dan Keller (2012) mengidentifikasikan iklan sebagai segala bentuk yang berbayar dari presentasi non personal dan promosi dalam bentuk ide, barang, ataupun jasa dari sponsor yang telah ditentukan.

Salah satu jenis iklan adalah iklan YouTube yang dapat diklasifikasikan menjadi dua jenis, yakni in stream video dan in video. In stream video yang berdurasi 15 detik membiarkan penonton melihat iklan terlebih dahulu, atau dapat menekan tombol skip setelah setidaknya 5 detik diputar. Sedangkan in video merupakan iklan yang muncul ketika video dimulai, mempunyai ukuran yang 
minim dibandingkan video yang diputar dan dapat di close atau minimize setelah 15 detik diputar. (Dehghani, et al., 2016)

Suatu iklan dapat dikatakan efektif apabila tujuan dari periklanan tercapai atau terlaksana. Tujuan dari pembuatan iklan harus dapat menginformasikan, membujuk, dan mengingatkan pembeli tentang produk yang ditawarkan oleh perusahaan (Purnama, 2001). Dari berbagai model yang dikembangkan untuk menganalisa tingkat efektivitas iklan, terdapat model yang dikembangkan oleh lembaga riset AC Nielsen yakni EPIC (Empathy, Persuasion, Impact, dan Communication) Model.

Variabel Empathy (empati), menginformasikan apakah konsumen menyukai suatu bentuk komunikasi pemasaran dan bagaimana konsumen melihat hubungan dengan dirinya. Empati melibatkan afeksi (perasaan) dan kognisi (pemikiran) sebagai tanggapan internal psikologis yang dimiliki oleh konsumen terhadap rangsangan dari lingkungannya (Peter dan Olson, 1999). Variabel persuasion (persuasi) merujuk pada penguatan karakter merek melalui komunikasi pemasaran, sehingga menarik keinginan konsumen untuk membeli. Variabel selanjutnya adalah impact (dampak) yang menunjukkan apakah suatu merek dapat terlihat lebih menonjol dibandingkan merek lain dalam kategori yang serupa, dan apakah iklan mampu menarik perhatian konsumen dalam pesan yang disampaikan. Variabel terakhir adalah communication (komunikasi) yang memberikan informasi mengenai kemampuan konsumen dalam mengingat pesan utama yang disampaikan, pemahaman konsumen, serta kekuatan kesan yang ditinggalkan oleh pesan tersebut. (Durianto, et al., 2003)

Semua variabel di atas berpengaruh ke dalam keputusan pembelian yang memiliki pengertian berupa tindakan konsumen untuk menentukan membeli produk yang telah ia lihat atau tidak (Kotler dan Keller, 2012). Keputusan pembelian memiliki beberapa tahap di dalamnya yang dilalui oleh konsumen. 
Tahapan pertama adalah pengenalan masalah di mana konsumen berusaha mengenali masalah melalui pemicu, baik dari dalam maupun luar. Setelah itu, dilakukan tahap pencarian informasi yang berguna untuk memperkuat keputusan serta produk yang diinginkan. Tahapan ketiga adalah evaluasi alternatif, ketika konsumen cenderung akan mencari informasi tambahan tentang produk alternatif yang ingin dikonsumsi agar mendapatkan manfaat sebanyakbanyaknya. Pada tahap keempat, konsumen menentukan produk yang akan dikonsumsi dan melakukan keputusan pembelian. Terakhir, terdapat tahap perilaku pasca pembelian dimana konsumen mengalami kepuasan atau ketidakpuasan terhadap produk yang telah dikonsumsi. Perilaku ini akan menentukan pembelian ulang pada diri konsumen (Kotler dan Keller, 2012).

Berdasarkan kajian teori diatas, maka dapat disusun sebuah kerangka pemikiran sebagai berikut:

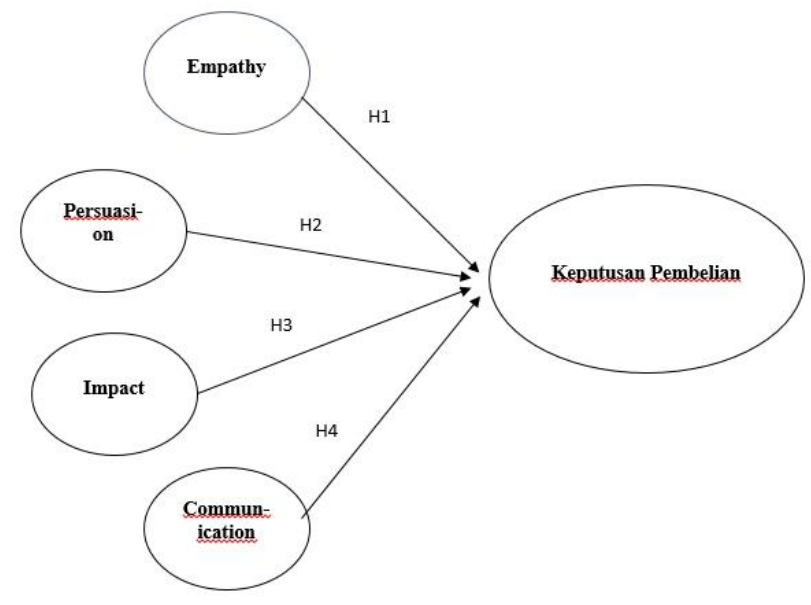

Gambar 1 Kerangka Pemikiran Sumber: AC Nielsen (2000)

Berdasarkan kerangka tersebut, maka hipotesis penelitian yang diajukan adalah:

$\mathrm{H} 1$ : Variabel empathy efektif terhadap keputusan pembelian

$\mathrm{H} 2$ : Variabel persuasion efektif terhadap keputusan pembelian

H3: Variabel impact efektif terhadap keputusan pembelian

$\mathrm{H} 4$ : Variabel communication efektif terhadap keputusan pembelian 


\section{METODE PENELITIAN}

Penelitian ini menggunakan paradigma positivisme. Penelitian dilakukan menggunakan pendekatan kuantitatif dengan mengambil karyawan sebagai populasi penelitian (baik karyawan swasta maupun pegawai negeri sipil), sedangkan sampel yang dipilih sebagai responden merupakan karyawan yang bekerja dan berdomisili di DKI Jakarta. Sampel dipilih menggunakan non probability sampling dengan teknik penarikan sampel berdasarkan quota. Quota sampling yang digunakan termasuk dalam jenis non proporsional dengan minimum jumlah laki-laki atau perempuan sejumlah 35 , dan total responden yang terlibat dalam penelitian ini berjumlah 120 orang.

Data penelitian diperoleh melalui pengisian kuesioner yang disebarkan secara online kepada karyawan yang bekerja dan berdomisili di DKI Jakarta. Teknik pengumpulan data melalui kuesioner tersebut merupakan salah satu teknik dari metode self-report. Metode ini didasari dari laporan tentang diri sendiri dan pada pengetahuan serta keyakinan pribadi (Sugiyono, 2010). Selain kuesioner, data juga didapatkan melalui studi literatur dengan mengumpulkan teori melalui buku, artikel, jurnal dan skripsi terdahulu.

Untuk mengukur jawaban responden dalam kuesioner penelitian ini, digunakan Skala Likert. Skala Likert tepat untuk digunakan karena dapat mengukur sikap, pendapat, dan persepsi seseorang atau sekelompok orang tentang fenomena sosial. (Sugiyono, 2010)

Tabel 1 Skala pengukuran Likert

\begin{tabular}{clc}
\hline Tanda & \multicolumn{1}{c}{ Keterangan } & Bobot \\
\hline SS & Sangat Setuju & 5 \\
\hline S & Setuju & 4 \\
\hline RR & Ragu - Ragu & 3 \\
\hline TS & Tidak Setuju & 2 \\
\hline STS & Sangat Tidak Setuju & 1 \\
\hline & Sumber: Sugiyono (2010)
\end{tabular}


Untuk memastikan akurasi dan ketepatan data, jawaban kuesioner diuji validitas dan reliabilitasnya menggunakan IBM SPSS Statistic 23. Uji validitas dilakukan menggunakan Kaiser-Meyer-Olkin Measure of Sampling Adequacy, sementara uji reliabilitas menggunakan Cronbach's Alpha. Setelah itu data diolah menggunakan EPIC Model yang digagas oleh AC Nielsen untuk mengukur efektivitas iklan berdasarkan empat variabel yang telah dideskripsikan sebelumnya pada tabel. Model ini dapat menampilkan kemampuan konsep dalam basis multidimensional serta dapat menafsirkan konsep yang gagal dalam suatu variabel tertentu (Nielsen, 2000).

Dalam menganalisis efektivitas iklan pada permasalahan ini, penulis menggunakan analisa tabulasi sederhana dan penghitungan rata-rata terbobot. Dalam analisa tabulasi sederhana, data yang diperoleh kemudian diolah ke dalam bentuk persentase dengan menggunakan rumus sebagai berikut (Durianto, et al., 2003) $p=\frac{f i}{\Sigma f i} \times 100 \%$

Dengan keterangan:

$p \quad$ : persentase responden yang memilih kategori tertentu

fi : jumlah responden yang memilih kategori tertentu

$\Sigma f i \quad$ : Jumlah total responden

Jika dilihat berdasarkan bobot yang tercantum di dalam setiap hasil jawaban kuisioner, dihitung skor rata-rata dengan rumus sebagai berikut (Durianto,et al., 2003):

$$
x=\frac{\Sigma f i . w i}{\Sigma f i}
$$

Dengan rincian sebagai berikut:

$x \quad$ : rata-rata bobot

fi : frekuensi

wi : bobot 
Langkah selanjutnya adalah dengan menghitung rentang skala penilaian yang disesuaikan berdasarkan skala Likert, dengan rumus sebagai berikut: (Durianto, et al., 2003)

$$
R s=\frac{R(b o b o t)}{M}
$$

Dimana:

Rs : Rentang skala

$R$ (bobot) : Bobot terbesar-bobot terkecil

M : Banyaknya kategori bobot

Berdasarkan skala Likert dengan bobot 1 sampai 5, diperoleh perhitungan sebagai berikut:

$$
R s=\frac{5-1}{5}=0.8
$$

Sehingga menghasilkan posisi keputusan EPIC model sebagai berikut:

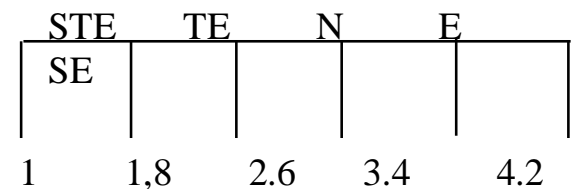

Tahap terakhir adalah dengan mengukur EPIC rate dengan rumus berikut:

$$
p=(\Sigma f i . x i) / N
$$

Angka yang dihasilkan oleh EPIC rate tersebut akan menggambarkan posisi efektivitas sesuai dengan resepsi responden.

Skala penilaian yang berlaku dalam perhitungan adalah sebagai berikut:

$1,00-1,80$ = Sangat Tidak Efektif

1,81-2,6 = Tidak Efektif

2,61-3,41 = Cukup Efektif 
3,41-4,20 = Efektif

4.21-5,00 = Sangat Efektif

\section{HASIL DAN DISKUSI}

Berdasarkan hasil kuesioner yang telah dibagikan kepada 120 responden secara online, maka diperoleh data demografi yang dapat dibedakan berdasarkan jenis kelamin, usia, domisili, dan lokasi pekerjaan.

Tabel 2 Demografi responden

\begin{tabular}{|c|c|c|}
\hline Demografi & Jumlah responden (orang) & $\%$ \\
\hline \multicolumn{3}{|l|}{ Jenis Kelamin } \\
\hline Laki-laki & 43 & 35.8 \\
\hline Perempuan & 77 & 64.2 \\
\hline \multicolumn{3}{|l|}{ Usia (tahun) } \\
\hline $20-25$ & 94 & 78.3 \\
\hline $26-30$ & 13 & 10.8 \\
\hline $31-35$ & 6 & 5 \\
\hline $36-40$ & 2 & 1.6 \\
\hline$>41$ & 5 & 4.17 \\
\hline \multicolumn{3}{|l|}{ Domisili } \\
\hline Jakarta Pusat & 6 & 5 \\
\hline Jakarta Timur & 26 & 21.7 \\
\hline Jakarta Selatan & 68 & 56.7 \\
\hline Jakarta Barat & 14 & 11.7 \\
\hline Jakarta Utara & 6 & 5 \\
\hline \multicolumn{3}{|l|}{ Lokasi Pekerjaan } \\
\hline Jakarta Pusat & 27 & 22.5 \\
\hline Jakarta Timur & 15 & 12.5 \\
\hline Jakarta Selatan & 60 & 50 \\
\hline Jakarta Barat & 11 & 9.2 \\
\hline Jakarta Utara & 7 & 5.8 \\
\hline Total Responden & 120 & $100 \%$ \\
\hline
\end{tabular}

Sumber: Dinda, Rara, Irwansyah (2017) 


\section{Uji Validitas dan Reliabilitas}

Dengan perhitungan Kaiser-Meyer-Olkin Measure of Sampling Adequacy dan Cronbach's Alpha, validitas dan reliabilitas jawaban responden menunjukkan hasil yang valid dan reliabel untuk diteliti lebih lanjut.

Tabel 3 Uji validitas dan reliabilitas

\begin{tabular}{lcc}
\hline \multicolumn{1}{c}{ Variabel } & KMO & Cronbach's Alpha \\
\hline Empathy & 0.500 (Valid) & 0.601 (Reliabel) \\
\hline Persuasion & 0.500 (Valid) & 0.731 (Reliabel) \\
\hline Impact & 0.500 (Valid) & 0.642 (Reliabel) \\
\hline Communication & 0.500 (Valid) & 0.727 (Reliabel) \\
\hline
\end{tabular}

Sumber: Dinda, Rara, Irwansyah (2017)

Dari tabel di atas, dapat disimpulkan bahwa seluruh variabel memiliki reliabilitas yang cukup tinggi. Sementara, hasil validitas menunjukkan angka yang sama antara satu variabel dengan yang lain, dengan hasil yang moderat yaitu 0,5.

\section{Variabel empathy}

Variabel empathy (empati) menginformasikan apakah konsumen menyukai iklan Youtube Traveloka dan menggambarkan bagaimana konsumen melihat hubungan antara suatu iklan dengan pribadi mereka. Hasil perhitungan variabel ini dapat dilihat pada tabel dibawah. Variabel empathy diwakili beberapa pertanyaan yaitu:

1. Menonton iklan tersebut membuat saya senang dan terhibur

2. Menonton iklan tersebut melibatkan aspek pemikiran (persepsi) saya terhadap Traveloka 
Tabel 4 Hasil perhitungan variabel empathy terhadap iklan

\begin{tabular}{llll}
\hline \multicolumn{1}{c}{ Atribut } & Bobot & e1 & e2 \\
\hline Sangat tidak setuju & 1 & 4 & 2 \\
Tidak setuju & 2 & 13 & 4 \\
Netral & 3 & 46 & 20 \\
Setuju & 4 & 38 & 69 \\
Sangat Setuju & 5 & 19 & 25 \\
& & & $\mathbf{1 2 0}$ \\
\hline
\end{tabular}

Sumber: Dinda, Rara, Irwansyah (2017)

$\mathrm{X}(\mathrm{e} 1)=\frac{(4 * 1)+(13 * 2)+(46 * 3)+(38 * 4)+(19 * 5)}{120}=3,46$

$\mathrm{X}(\mathrm{e} 2)=\frac{(2 * 1)+(4 * 2)=(20 * 3)+(69 * 4)+(25 * 5)}{120}=3,92$

$\mathrm{X}($ empathy $)=\frac{3,46+3,92}{2}=3,69$

Berdasarkan perhitungan diatas, hasil analisis variabel empathy pada iklan Youtube Traveloka menunjukkan bahwa iklan tersebut termasuk dalam kategori efektif (H1 terbukti). Hal ini menunjukkan bahwa iklan tersebut dapat memberikan informasi dan pesan yang menarik sehingga disukai oleh konsumen.

\section{Variabel Persuasion (Persuasi)}

Pertanyaan pada variabel persuasion (persuasi) memberikan informasi dari iklan Youtube Traveloka untuk peningkatan atau penguatan karakter suatu merek. Hasil perhitungan variabel ini dapat dilihat pada tabel di bawah. Variabel persuasion diwakili oleh beberapa pertanyaan, yaitu:

1. Setelah menonton iklan tersebut, saya ingin mengetahui lebih lanjut mengenai produk dan keunggulan Traveloka

2. Setelah menonton iklan tersebut, saya ingin menggunakan situs aplikasi/ web Traveloka untuk mencari tiket penerbangan 
Tabel 5 Hasil perhitungan variabel persuasion terhadap iklan

\begin{tabular}{llcc}
\hline \multicolumn{1}{c}{ Atribut } & Bobot & p1 & p2 \\
\hline Sangat tidak setuju & 1 & 2 & 1 \\
Tidak setuju & 2 & 5 & 7 \\
Netral & 3 & 23 & 20 \\
Setuju & 4 & 66 & 48 \\
Sangat Setuju & 5 & 24 & 44 \\
\hline
\end{tabular}

Sumber: Dinda, Rara, Irwansyah (2017)

$X(p 1)=\frac{(2 * 1)+(5 * 2)+(23 * 3)+(66 * 4)+(24 * 5)}{120}=3,88$

$\mathrm{X}(\mathrm{p} 2)=\frac{(1 * 1)+(7 * 2)+(20 * 3)+(48 * 4)+(44 * 5)}{120}=4,05$

$X($ persuasion $)=\frac{3,88+4,05}{2}=3,965 \rightarrow 3,97$

Berdasarkan perhitungan diatas, hasil analisis variabel persuasion pada iklan Youtube Traveloka menunjukkan bahwa iklan tersebut termasuk dalam kategori efektif ( $\mathrm{H} 2$ terbukti). Hal ini menunjukkan bahwa iklan tersebut cukup dapat meningkatkan dan menguatkan karakter Traveloka dalam benak konsumen, serta memiliki dampak keinginan konsumen untuk menggunakan aplikasi Traveloka.

\section{Variabel Impact (Dampak)}

Pertanyaan pada variabel impact (dampak) menunjukkan apakah Iklan Youtube Traveloka terlihat menonjol dibanding iklan lain pada kategori yang serupa dan apakah iklan mampu melibatkan konsumen dalam pesan yang disampaikan. Hasil perhitungan variabel ini dapat dilihat pada tabel dibawah. Pertanyaan pada variabel impact (dampak) memberikan informasi tentang perasaan konsumen keunggulan iklan Traveloka terhadap iklan lain serta pelibatan konsumen dalam iklan yang ditayangkan. 
Variabel dampak diwakili beberapa pertanyaan yaitu:

1. Saya rasa Iklan tersebut lebih unggul dibandingkan dengan iklan travel agent kompetitor Indonesia lainnya.

2. Saya merasa dilibatkan di dalam pesan Iklan tersebut.

Tabel 6 Hasil perhitungan variabel impact terhadap iklan

\begin{tabular}{lclc}
\hline \multicolumn{1}{c}{ Atribut } & Bobot & i1 & i2 \\
\hline Sangat tidak setuju & 1 & 1 & 4 \\
Tidak setuju & 2 & 2 & 11 \\
Netral & 3 & 23 & 52 \\
Setuju & 4 & 53 & 40 \\
Sangat Setuju & 5 & 41 & 13 \\
\hline
\end{tabular}

Sumber: Dinda, Rara, Irwansyah (2017)

$X(\mathrm{i} 1)=\frac{(1 * 1)+(2 * 2)+(23 * 3)+(53 * 4)+(41 * 5)}{120}=4,1$

$X(i 2)=\frac{(4 * 1)+(11 * 2)+(52 * 3)+(40 * 4)+(13 * 5)}{120}=\mathbf{3}, \mathbf{4}$

$X($ impact $)=\frac{4,1+3,4}{2}=3,75$

Berdasarkan perhitungan diatas, hasil analisis variabel impact pada iklan Youtube Traveloka menunjukkan bahwa iklan tersebut termasuk dalam kategori efektif (H3 terbukti). Hal ini menunjukkan bahwa iklan Youtube Traveloka terlihat menonjol dibanding merek lain pada kategori yang serupa dan iklan mampu melibatkan konsumen dalam pesan yang disampaikan.

\section{Variabel Communication (Komunikasi)}

Pertanyaan pada variabel komunikasi (communication) memberikan informasi tentang kemampuan konsumen dalam mengingat pesan utama yang disampaikan, pemahaman konsumen, serta kekuatan pesan yang ditinggalkan pesan tersebut. Hasil perhitungan variabel ini dapat dilihat pada Tabel 13. 
Variabel communication diwakili oleh beberapa pertanyaan yaitu:

1. Saya mudah menangkap iklan pesan yang disampaikan oleh iklan Traveloka

2. Iklan Traveloka meninggalkan kesan yang positif bagi saya

Tabel 7 hasil perhitungan variabel communication terhadap iklan

\begin{tabular}{llll}
\hline \multicolumn{1}{c}{ Atribut } & Bobot & c1 & c2 \\
\hline Sangat tidak setuju & 1 & 0 & 0 \\
Tidak setuju & 2 & 0 & 1 \\
Netral & 3 & 10 & 16 \\
Setuju & 4 & 64 & 70 \\
Sangat Setuju & 5 & 46 & 33 \\
\hline & & & $\mathbf{1 2 0}$ \\
\hline
\end{tabular}

Sumber: Dinda, Rara, Irwansyah (2017)

$X(c 1)=\frac{(0 * 1)+(0 * 2)+(10 * 3)+(64 * 4)+(46 * 5)}{120}=4,3$

$X(c 2)=\frac{(0 * 1)+(1 * 2)+(16 * 3)+(70 * 4)+(30 * 5)}{120}=4$

$\mathrm{X}($ communication $)=\frac{4,3+4}{2}=4,15$

Berdasarkan perhitungan diatas, hasil analisis variabel communication pada iklan Youtube Traveloka menunjukkan bahwa iklan tersebut termasuk dalam kategori efektif ( $\mathrm{H} 4$ terbukti). Hal ini menunjukkan bahwa iklan Youtube Traveloka mampu membuat konsumen mengingat pesan utama yang disampaikan serta meningkatkan pemahaman konsumen dan juga mengingat pesan yang disampaikan. 
Gambar skala gabungan dari masing-masing variabel tersaji di bawah ini:

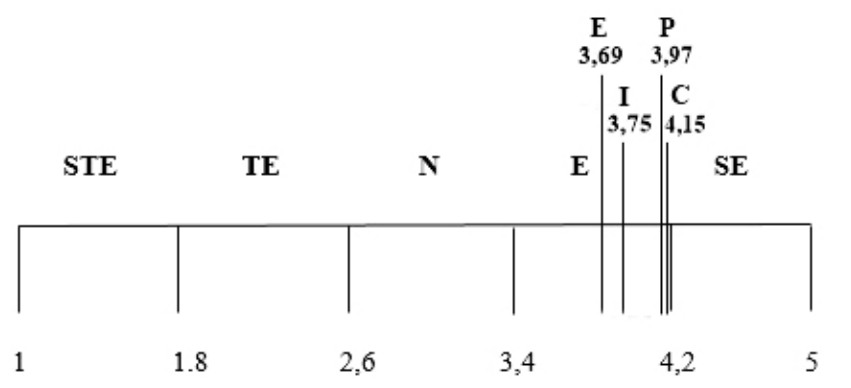

Gambar 2 Skala Gabungan

Sumber: Dinda, Rara, Irwansyah (2017)

Berikutnya hasil dari masing-masing variabel EPIC di rata-ratakan menjadi EPIC rate, sebagai berikut :

$E P I C$ rate $=\frac{\text { empathy }+ \text { persuasion }+ \text { impact }+ \text { communication }}{4}$

$$
=\frac{3,69+3,97+3,75+4,15}{4}=3,89
$$

Hasil akhir dari 3,89 yang termasuk dalam kategori efektif. Hal ini memperlihatkan bahwa iklan Youtube Traveloka memiliki dampak yang hampir maksimal. Efektivitas iklan pada EPIC yang sempurna seharusnya memiliki hasil rate lima dalam semua variabel. Hasil sempurna menggambarkan suatu iklan dapat menarik penonton hingga melakukan keputusan pembelian. Walapun EPIC rate dalam penelitian ini belum mencapai tingkat sempurna, namun iklan yang kami teliti dapat memengaruhi keputusan pembelian karna tergolong efektif. Grafik hasil analisis efektivitas iklan Youtube Traveloka dengan metode EPIC Model tersaji di bawah ini. 


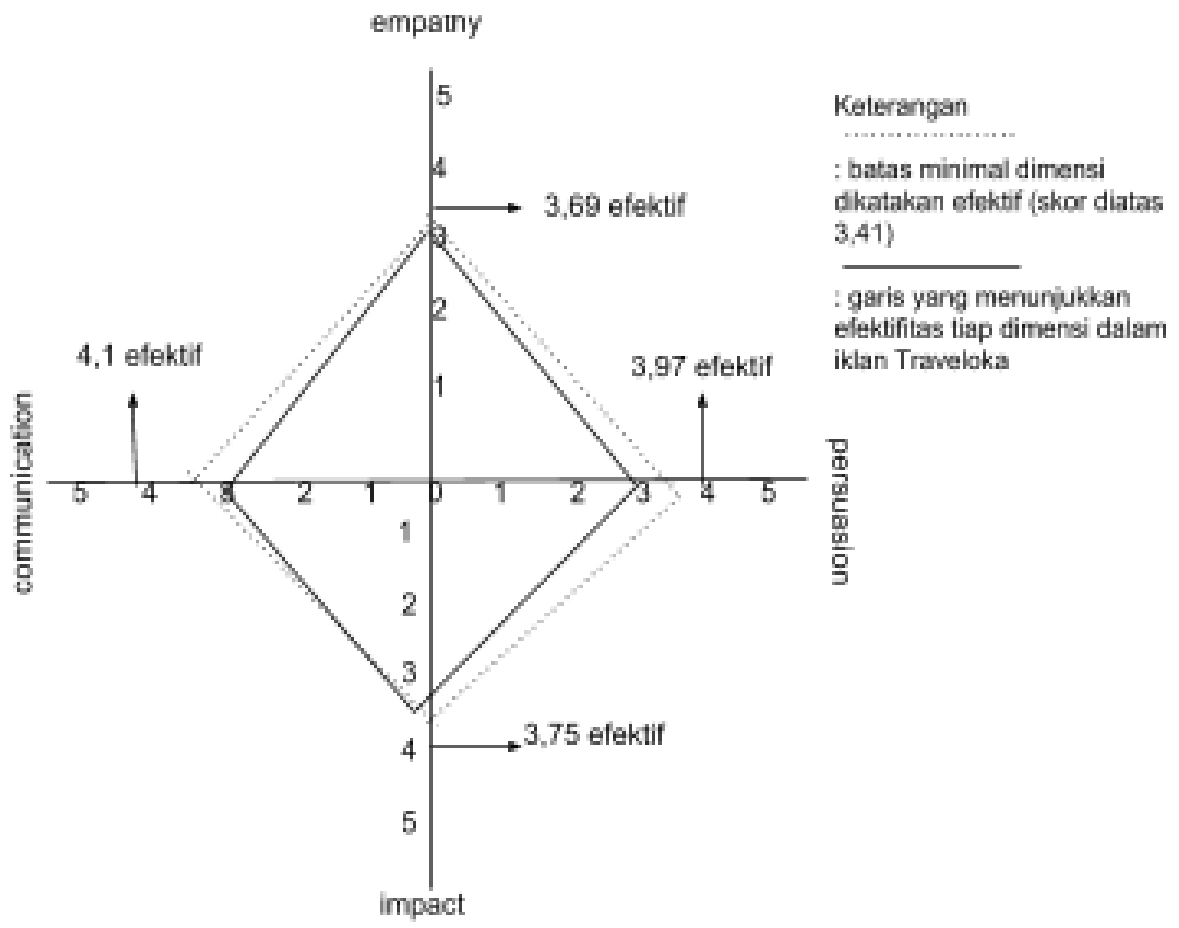

Gambar 2 EPIC model ikg

Gambar 3 Hasil Efektivitas Iklan

Sumber: Dinda, Rara, Irwansyah (2017)

Pada hasil penelitian, terlihat jelas bahwa model EPIC mempengaruhi keputusan pembelian konsumen, terutama dalam variabel communication dengan angka sebesar 4,15. Hal ini menunjukkan bahwa iklan Youtube Traveloka terbukti mampu meninggalkan kesan positif dalam pikiran para konsumen dan mampu membuat konsumen mengingat pesan utama yang disampaikan. Sehubungan dengan pertanyaan dalam variabel communication, iklan Youtube Traveloka berhasil menciptakan iklan dengan komunikasi yang efektif dan tidak tersirat, sehingga konsumen dapat menangkap pesan dari iklan dengan mudah. Hal yang dapat digarisbawahi dalam penelitian kami yaitu penggunaan EPIC Model yang terfokus dan sesuai dengan produk yang kami teliti, sehingga menghasilkan angka dan tingkat efektivitas yang tinggi.

Penelitian ini didukung oleh penelitian sebelumnya dalam beberapa hal. 
Salah satunya, untuk penelitian mengenai EPIC model dari Shoreana dan Najib (2015) yang menggunakan metode analisis data yang sama. Namun dalam penelitian ini, penulis menggabungkan hasil angka EPIC dari masing-masing variabel dalam satu skala. Dengan membandingkan penelitian Shoreana, peneliti berpendapat bahwa dengan menekankan analisis penelitian pada satu model saja dapat menjadikan penelitian lebih terfokus, terlebih ada beberapa indikator yang ada didalam model AIDA dapat dimasukkan pula pada model EPIC.

Penelitian Darvian Dio Prakoso (2015) yang berjudul "Analisis Efektivitas Iklan PT. Traveloka Indonesia di Televisi (Studi Pada Mahasiswa Fakultas Ekonomi dan Bisnis Universitas Brawijaya Malang) juga merupakan salah satu acuan dalam penulisan kami. Dengan topik besar penelitian yang sama, penelitian Prakoso berfokus pada iklan televisi dan menganalisis iklan Traveloka secara keseluruhan. Hasil variabel persuasion dalam penelitian Prakoso menunjukkan angka yang tergolong netral, berbeda dengan hasil variabel persuasion dalam penelitian ini yang tergolong efektif dengan nilai 3,97. Secara garis besar, penelitian kami mendukung penelitian sebelumnya dengan hasil yang menyatakan bahwa variabel EPIC dari iklan Traveloka terbukti efektif sehingga dapat memengaruhi keputusan pembelian. Penelitian kami pun turut memperbaiki penelitian sebelumnya dengan hasil efektivitas EPIC Model tiap variabel yang menunjukkan angka lebih tinggi dibandingkan hasil penelitian sebelumnya yang dilakukan oleh Prakoso.

\section{KESIMPULAN}

Pengukuran efektivitas iklan Traveloka versi "Saat Memesan Tiket Pesawat tak Lagi Ribet" dengan pendekatan EPIC Model dilakukan untuk mendapatkan nilai tingkat variabel empathy, persuasion, impact dan communication. Dengan hasil epic rate sebesar 3.89, iklan dianggap telah mencapai kategori efektif. Ada baiknya apabila perusahaan dapat mempertahankan dan meningkatkan kualitas untuk iklan selanjutnya, baik melalui sisi strategi maupun teknis. Untuk penelitian 
selanjutnya, peneliti menyarankan penulis untuk menggali indikator lain yang belum dijabarkan dalam penelitian ini agar dapat memperkaya dan memperkuat hasil, dikarenakan banyaknya indikator dari setiap variabel EPIC yang berbedabeda pada setiap penelitian.

\section{DAFTAR PUSTAKA}

AC Nielsen. 2000. Ads@work: Make your advertising work for your brand. [pdf] Tersedia di $<\underline{\text { http://www.nielsen.com/content/dam/nielsen/en_us/documents/pdf/F }}$ act\%20Sheets/Nielsen\%20ads@work\%20brochure.pdf> [Diakses 12 Desember 2017].

APJII (Asosiasi Penyelenggara Jasa Internet Indonesia). 2016. Hasil Survey 2016. [online] Tersedia di <http://www.apjii.or.id/survei2016> [Diakses 15 Desember 2017].

Dehghani, et al. 2016. Evaluating The Influence of YouTube Advertising For Attraction of Young Customers. Journal of Computers in Human Behaviour, [e-journal] Volume 59, 165-172. Tersedia di <https://www.sciencedirect.com/science/article/pii/S074756321630045> [Diakses 8 Desember 2017].

Durianto, et al. 2003. Invasi Pasar Dengan Iklan Yang Efektif. Jakarta: PT Gramedia Pustaka

Forbes Indonesia. 2016. 20 Rising Global Stars. Forbes Indonesia, [Online] 9 Mei. Tersedia di <http://forbesindonesia.com/navcategory-83-4.html $>$ [Diakses 11 Desember 2017].

Grimes, M. 2012. Nielsen: Global Consumers' Trust In 'Earned' Advertising Grows in Importance. [online] Tersedia di <http://www.nielsen.com/us/en/press-room/2012/nielsen-global- 
consumers-trust-in-earned-advertising-grows.html> [Diakses 15 Oktober 2017].

Kementerian Komunikasi dan Informasi. 2015. Klasifikasi Jasa yang Digunakan dalam Transaksi Online Tahun 2015. [online] Tersedia di <https://statistik.kominfo.go.id/site/data?idtree=430\&iddoc=1459\&datadata page $=3>$ [Diakses 11 Desember 2017].

Kementerian Pariwisata. 2014. Statistik Profil Wisatawan Nusantara 2014 [pdf] Tersedia di <www.kemenpar.go.id/userfiles/Wisnus\%202014.pdf> [Diakses 11 Desember 2017].

Kotler, P., Keller K.L. 2012. Manajemen Pemasaran. Jakarta: Erlangga.

Perrin, A. 2015. Social Media Usage: 2005-2015. Pew Research Center: Internet \& Technology, [online] 8 Oktober. Tersedia di <http://www.pewinternet.org/2015/10/08/social-networking-usage2005-2015/> [Diakses 16 Oktober 2017].

Peter, J.P., Olson, J.C. 1999. Perilaku Konsumen dan Strategi Pemasaran, Edisi keempat (terjemahan). Jakarta : Erlangga.

Prakoso, D.D. 2014. Analisis Efektivitas Iklan PT. Traveloka Indonesia di Televisi

(Studi Pada Mahasiswa Fakultas Ekonomi Dan Bisnis Universitas Brawijaya Malang). Jurnal IImiah Mahasiswa FEB Universitas Brawijaya, [e-journal] Volume 3. Tersedia di <http://jimfeb.ub.ac.id/index.php/jimfeb/article/view/2237. $>$ [Diakses 11 Desember 2014].

Pro Similar Web. 2017. Website Analysis Overview Report Traveloka.com. [pdf] Tersedia di <https://pro.similarweb.com/\#/website/trafficsocial/traveloka.com/*/999/3m> [Diakses 15 Oktober 2017]. 
Purnama, L. 2001. Strategic Marketing Plan: Panduan Lengkap dan Praktis Menyusun Rencana Pemasaran yang Strategis dan Efektif. Jakarta: PT Gramedia Pustaka Utama.

Sugiyono. 2010. Metode Penelitian Bisnis. Bandung: CV Alfabeta.

Shoreana, T., Najib, M. 2015. Analisis Efektivitas Iklan Televisi Sari Manggis Mastin Dengan Menggunakan Model AIDA dan EPIC. Institut Pertania Bogor (IPB). Tersedia di <http://repository.ipb.ac.id/handle/123456789/75076> [Diakses 18 Desember 2017].

Widiartanto, Y.H. 2015. Ini Dia, Daftar Aplikasi Terbaik di Google Play Indonesia. Kompas, [online] 3 Desember. Tersedia di

<http://tekno.kompas.com/read/2015/12/03/13423657/Ini.Dia.Daftar.Aplikasi.T erbaik.di.Google.Play.Indonesia> [Diakses 11 Desember 2017]. 